Etnográfica

Revista do Centro em Rede de Investigação em

Antropologia

vol. $26(1) \mid 2022$

Vol. $26(1)$

\title{
From coconut to land: changing livelihoods in Micaúne, Central Mozambique
}

Do coco à terra: mudanças nos meios de vida em Micaúne, Centro de

Moçambique

José Laimone Adalima

\section{(2) OpenEdition}

Journals

Electronic version

URL: https://journals.openedition.org/etnografica/11067

DOI: $10.4000 /$ etnografica. 11067

ISSN: 2182-2891

Publisher

Centro em Rede de Investigação em Antropologia

Printed version

Number of pages: $29-50$

ISSN: 0873-6561

Electronic reference

José Laimone Adalima, "From coconut to land: changing livelihoods in Micaúne, Central

Mozambique", Etnográfica [Online], vol. 26 (1) | 2022, Online since 25 February 2022, connection on 30 June 2022. URL: http://journals.openedition.org/etnografica/11067 ; DOI: https://doi.org/10.4000/ etnografica. 11067

Etnográfica is licensed under a Creative Commons Attribution-NonCommercial 4.0 International License. 


\section{From coconut to land: changing livelihoods in Micaúne, Central Mozambique}

\section{José Laimone Adalima}

This paper is about how people in Micaúne currently generate their livelihoods in the aftermath of the coconut economy, which collapsed in the 2000s due to the upsurge of the coconut lethal yellowing disease (CLYD) in the early 1990s. This created uncertainty among residents; however, they did not migrate in masses as documented in the literature on livelihood shocks. On the contrary, Micaúne residents have adopted a different strategy of waiting and observing, since they believe that their future lies in their land because of the potential wealth that could possibly materialise from their subsoil (anticipation). This highlights a major shift of land from a mere host for palm trees into a valuable commodity.

KEYWORDS: coconut economy, livelihoods, land, Micaúne, Société du Madal.

Do coco à terra: mudanças nos meios de vida em Micaúne, Centro de Moçambique - Este artigo analisa como os habitantes de Micaúne produzem os seus meios de vida na atualidade, após o colapso, na primeira década de 2000, da centenária economia do coco, devido ao surgimento da doença do amarelecimento letal do coco, que assolou a região no início da década de 1990. Esta situação criou incerteza e desespero entre os habitantes que, contrariando a literatura sobre as crises dos modos de vida, não migraram em massa. Pelo contrário, eles adotaram uma estratégia de esperar para ver, pois acreditam que o seu futuro será materializado pelo potencial de riqueza que jaz no subsolo (teoria de antecipação). Portanto, o artigo destaca uma mudança na conceção sobre a terra, de um mero hospedeiro de palmares para uma mercadoria mais valiosa.

PALAVRAS-CHAVE: economia do coco, meios de vida, terra, Micaúne, Société du Madal.

ADALIMA, José Laimone (jose.adalima@uem.mz) - Departamento de Arqueologia e Antropologia, Universidade Eduardo Mondlane, Moçambique. 


\section{INTRODUCTION}

Historically Mozambique has been characterised by two types of economies that are geographically circumscribed, namely, a labour reserve for the South African mines, located in the southern part of the country, and a complex of plantations (such as cotton, tea, sisal, coconut, sugar, just to mention a few), which was developed in the northern region of the country.

There is abundant literature on the labour reserve economy that explains a relation of dependence, and mutual obligation, between migrant mineworkers in South African mines and their rurally based wives and kin back in Mozambique as the centre of both the social and the economic system (Newitt 1974; First 1983; Harries 1994). However, little research exists concerning the plantations' economy based on coconut, where notable exceptions are Vail and White (1980) and Negrão (1995). ${ }^{1}$ This paper is a contribution to the plantations' economies literature, which integrated wage-labour with smallholder peasant production.

Like labour reserves, plantations economies revolved around a symbiotic relationship between companies and local inhabitants as explored further in this paper. I illustrate this argument through the centennial coconut economy, which was developed at the turn of the eighteenth century by the French-owned Société du Madal (hereafter Madal) in central Mozambique in the administrative post of Micaúne (henceforward Micaúne), ${ }^{2}$ district of Chinde in Zambézia province. This paper was developed out of my $\mathrm{PhD}$ thesis and is based on an ethnographic study (combined with interviews, observations, and a survey) undertaken between 2011 and 2012 in Micaúne. It should be noted that at the time of my fieldwork, the management of Madal at the headquarters (in Quelimane) seemed not to be keen on providing relevant information and documentation or allowing employees to talk about the company. On the ground, in the plantations, there was also ongoing tension between the company and residents as I observed during fieldwork. For these reasons, I use fictitious names to protect the identity of my informants.

Through historical and ethnographic analysis I show how since its establishment Madal gradually transformed the local land tenure to fit the tenet of copra production. ${ }^{3}$ As a result, local inhabitants secured their livelihoods

I Most of the material (including legislation) I used for my research is in Portuguese and as a result, all references in Portuguese quoted in this paper are my own translations.

2 This is a direct translation of the Portuguese term posto administrativo, which is a subdivision of a district.

3 Copra is the oil extracted from dried kernel of the coconut, which has a multitude of uses such as in cooking, body and hair lotions, soaps and detergents, medications, lighting and engine fuel oil (Foale 2003). 
either through ownership of palm trees (they planted or purchased from other holders) or through seasonal labour working for Madal. This is because, historically, local households have been dedicated to growing food crops in a limited fashion only, and subsistence agriculture has never been more than a supplement to income generated through coconut production and trade and wage labour in this area.

However, this changed in the late 2000s due to the impact of a palm tree disease known as coconut lethal yellowing disease (CLYD), which is a mycoplasma infection that attacks the palm trees turning the leaves yellow and killing them in a short space of time. According to Eden-Green (2006), this disease started in Jamaica and it is currently very prevalent in Central and South America and Africa. In Mozambique, the first cases of the disease were reported in Cabo Delgado province in the 1950s and Zambézia province in the 1970s. But at the time, neither the leading companies in coconut production, like Madal and Boror, nor the colonial government in Mozambique was investing in coconut related research as compared with other regions (e.g. Latin America, the Caribbean and Asia) (Vail and White 1980).

It is not surprising that CLYD would spread over time in the country. According to Rønning (2000: 10) “Madal's coconut plantation in Micaúne was affected for the first time in March of 1998 and spread through local people' palms bordering the company's plantations".

As a result, the stability and predictability that people had enjoyed for so long turned into precariousness, uncertainty, and social instability. Yet, they did not migrate in masses contrary to what has already been documented in the literature on livelihood shocks. I use the concepts of wealth and anticipation to expand on why residents amidst the suffering have decided not to migrate. I follow Rakopoulos and Rio's (2018) definition of “wealth” as a store of value for future, and Stephan and Flaherty's (2019) definition of "anticipation" as the lived experience of individuals and communities' local worlds projected into the future. Both concepts articulate a trans-temporal function and temporalities, which helps explaining my findings.

Since the value of land depended on the trees planted on it, with the upsurge of CLYD there was a major shift in the way Micaúne residents conceived land from being a mere host of the palm trees into three new dimensions, which are: (a) land as a commodity; (b) land as a source of identity; and (c) land as the reserve of wealth. It is through these dimensions that Micaúne residents anticipate enjoying their "rightful share" from the land they live in.

The remainder of the paper presents the rise and fall of the coconut economy of Micaúne, the discussion of different dimensions of land, their implications for local livelihoods and final remarks. 


\section{THE RISE AND FALL OF THE COCONUT ECONOMY OF MICAÚNE}

The establishment of the coconut economy in Micaúne is one of the outcomes of Portugal's attempt to introduce land reforms to maximize Portuguese investments on the land under the Prazo system as well as to convert them into a modern administrative unit in response to the pressure put on it by other colonial powers, particularly after the Berlin Conference of 1884-1985. One of the deliberations of the conference was that colonial powers should prove that they de facto occupied territories they had historical claims to. The Portuguese colonial government was unable to ascertain that because it was militarily, administratively and economically weak (e.g. the Prazos disregard of the Crown).

The Prazos was an institution established in Mozambique along the Zambezi river valley by the Portuguese Crown in the $16^{\text {th }}$ century and comprised of land grants for three generations with the mandatory or preferential succession in the female line. The Crown retained ownership rights but it ceded to others the use rights against payment of a leasing fee (Isaacman 1972; Rita-Ferreira 1983).

Due to their involvement in the trade of gold, ivory and slaves, the Prazos holders became very powerful to the point of ignoring the authority of the Portuguese Crown and even fighting against government supervision of their activities (Capela 1999). Through several laws, Portugal tried unsuccessfully to end the Prazos through prudent allocation of land concessions aimed at promoting Portuguese private investment in agriculture, settlements and mining. For instance, the government granted a land concession to the Mining Company of Zambézia, for the exploitation of coal and ironstone in the district of Tete in January 1873 (current Tete province). Following this, other companies were established, namely the Mozambique Opium Cultivating and Trading Company, which was granted a concession to the Prazo Maganja aquém Chire in 1874, and the Sugar Company of Mozambique in 1890 (Vail and White 1980).

In the same year, João Correia, nephew of Isidoro Correia and a long-standing Zambezian slave trader, together with Carlos Nandim Carvalho rented the Prazo Mahindo in Micaúne and founded the Correia and Carvalho Company. This company started producing bricks, cargo boats, and spirits from its sugar cane plantation and the sap of the Africans' palm trees (Vail and White 1980; Negrão 1995, 2001).

In 1877, the company Correia and Carvalho initiated the first major attempt at establishing massive coconut production in Micaúne with a small plantation of 70.000 palm trees. Additional investment by the company in 1883 led to an increasing coconut production reaching 130 tonnes annually by the end of the century. As a result, Correia and Carvalho company was able 
to reach a market share of $4 \%$ of the copra exported through Quelimane by 1891 (Vail and White 1980). This was possible because the company benefited significantly from the existing coconut production from the local African families, which can be traced back to the seventh century and by the turning of the 19 $9^{\text {th }}$ century (Vail and White 1980; Negrão 1995).

Notwithstanding these few notable cases, the overall objective to attract Portuguese-based investors for the Prazos was a failure. To protect its territories from other colonial powers in the aftermath of the Berlin Conference, the Portuguese government decided to lease two-thirds of Mozambique to foreign companies, while keeping control over the remaining area comprising the south of the Save river (currently Inhambane, Gaza and Maputo provinces). This led to the establishment of two main chartered companies - the Mozambique Company (created in 1888) and the Nyassa or Niassa Company (1891) and a leasing Company - Zambézia Company (1892) (Vail 1976).

These chartered companies were granted powers to: organise a police force to ensure the pacification of the territories under their jurisdiction; facilitate colonisation through the construction of infrastructure (especially roads); create and develop small industries (e.g. cotton and sugar); engage in trading agricultural surpluses and rural business; and ensure the transit of goods to neighbouring countries (mainly South Africa and Rhodesia) (Cabaço 2007).

Unlike the two chartered companies, the Zambézia Company had no chartered rights, which made it easy for the Portuguese government, which had shares in the Zambézia Company to sublease part of the company's territory. This resulted in the establishment of the following companies: Maganja Aquém Chire (founded in 1894), Boror (1898), Société du Madal (1903), Companhia Agrícola de Lugela (1906) and the Sena Sugar Estates (1920) (Serra 1980).

Of interest for this paper is Madal due to its relevance in the establishment of the coconut economy in Micaúne. However, it should be noted that throughout the colonial period, Madal and Boror (another French-owned company) were the two main copra producers and they exported entirely to European markets, especially Marseille (the main market), Hamburg, Antwerp, London, and Lisbon (Ribeiro 1932).

Regarding Madal, a year after its foundation the company acquired the Prazo Mahindo and the Mozambique Oil and Soap Company (Compagnie des Huileries et Savonneries de Moçambique) from the company Correia and Carvalho in 1904.

Madal was able to increase the share of copra exports from 6\% in 1903 to 10\% in 1913 (Negrão 1995: 68) as a result of the expansion of its palm trees as well as its incentives to local outgrowers.

By 1908, Madal had planted 544 acres of palm trees in Prazo Mahindo (Negrão 1995: 62) and by 1925, Prazo Mahindo had the largest number of palm trees among all Madal's Prazos with 2000 while Madal, Tangalane, 
Cheringone Prazos combined had 3000 and Inhassunge had 1200 (Muralha 1925: 172).

All in all, Madal controlled the whole coconut production chain and, at the same time, determined incentives to it by stimulating coconut production by local African families for which he determined the price and was the main purchaser. In this way, coconut became central to all activities in Micaúne and, in a sense, the whole society revolved around this cash crop. My informants commented that there was a little land that did not have palm trees on it. As Bertelsen (2014) puts it, Madal became "a total institution", meaning that the company determined, to a great extent, the living conditions of Micaúne residents as it was the major employer, mostly seasonal work for men, a supplier of goods through its shop and the main purchaser of coconut from growers in the area. Despite being a harsh system as indicated by my informants, the coconut economy remained unchanged amidst political and economic changes that have affected Mozambique in the past 100 years, such as decolonization, socialism, and neoliberalism.

The longevity of this economy can be explained by a combination of policy reforms, capitalist monopoly and its embeddedness in local social organisation and modes of production under the bilateral kinship system that prevailed in Micaúne for much of the $20^{\text {th }}$ century (Adalima 2020: 3).

According to the above-mentioned inheritance system, both sons and daughters inherited land and trees from their father and their mother, but for this to take place the children had to marry before the death of their parents. When a man or woman died the inheritance was divided into equal shares among the sons and daughters. Concerning the daughters, they were allowed to keep land inherited from their father despite moving to their husband's families after marriage. This explains why throughout the colonial and post-colonial periods every household made sure that there were enough trees to be inherited by the future generations. In this way, family plots and palm trees were scattered around the area making it difficult for families to have a concentration of large holdings (Negrão 1995).

However, the upsurge and spread of CLYD in the early 1990s led to the death of both Madal's and residents' palm trees, changing radically the local economy. The population previously involved (directly or indirectly) in coconut production became redundant. Moreover, the financial problems of the Sena Sugar Estate in Luabo (a neighbouring Administrative Post) and the loss of sugar jobs added to the decline of employment possibilities in the region. Despite this scenario, Madal did not leave the area - instead, is waiting for the disease to disappear while using the land for other purposes: promotion of cash crops such as sesame, game farming, and tourism - nor did he return the land to the local people. Similarly, Micaúne residents did not emigrate in masses in search of new or better living conditions elsewhere. This differs from 
many other places where people in similar situations have decided to leave for better living conditions (see e.g. McDowell and De Haan 1997). Micaúne residents, on the contrary, have adopted a different strategy of waiting and observing, since they believe that their future is on their land because of the promise of the materialisation of the wealth that lies in their subsoil.

When I did my fieldwork in 2011, the main sources of livelihoods for Micaúne residents were subsistence farming, petty trade, trade and formal employment. My findings show that most local people combined at least two of the first three livelihood options mentioned above while the last two were dominated by newcomers. It should be noted that none of the options that people are currently pursuing are, in fact, a significant replacement for coconut, but rather just attempts at making a living.

This marks a shift in the conception of land-use exclusively for agricultural purposes and suggests other dimensions through which people access sources of cash and other support from others (Ferguson 2013: 169).

In the next three sections, I discuss these new conceptions of land and their relation to the local people's livelihoods.

\section{CHANGING MEANINGS ATTRIBUTED TO LAND}

\section{Land as a commodity}

Following Karl Marx and others, Polanyi argued that before the rise of the market, land and labour were controlled and managed through persisting social relationships. As the market expanded, land and labour were "disembedded" from their social relations and turned into commodities (Polanyi 1944). Chimhowu and Woodhouse (2006: 359-360) show that "the commoditisation of access to land within the framework of customary tenure has been evident for more than a century and is now both more common and increasing".

According to Lastarria-Cornhiel (1997: 1324): "The major factor behind these changes is the transformation of land from a factor of production to a source of food and as an asset, from an abundant resource valued for its ability to provide income through coconuts to a scarce commodity that has cash value". Peters (2013) attributes changes in the meanings given to land elsewhere to the effects of structural adjustment programmes and market liberalisation policies, which led people to look to family and customary land as sources of food and cash.

The commodification of land in Micaúne is not a novelty. Land (or the trees standing on it) has been a commodity since the 1880s when the Portuguese government decided to make land concessions to private interests including private white farmers. This gained a new impetus in the 1960s because of legislative reforms that authorised new land concessions in the Zambezi Delta. These reforms aimed at promoting and establishing Portuguese settlements 
in the colonies, as an economic strategy to develop its empire by allowing the conversion of what was "indigenous reserve" into private settler holdings.

As a result, in Micaúne, in the 1960s and early 1970s, only six families were occupying an area of 1426 hectares used for livestock (Negrão 2001: 179). By 1973, private farmers controlled approximately 92.158 hectares in Micaúne (Negrão 2001: 174). Due to the discriminatory nature of the colonial laws and the excessive amounts required to purchase land, it was unusual for African families to buy land (Zamparoni 1998). However, through the transaction of palm trees, African families were able to expand their holdings.

Rights over land with palm trees belonged to the occupants and their children, entitling them to the right to reap the rewards at any time. Land transactions happened outside of state control, based on the evaluation of the number of trees, and attached plots. One could not sell land without trees on it (Negrão 2001: 218).

During this period, the sale of land was a complex process and followed certain rules. First, nobody could dispose of his or her entire area of land; second, the sale should be made in the presence of the local chiefs (Mwenes and Samassoas), as witnesses to sanction both a just evaluation and assess the reason for the transaction. Third, there should be a compelling reason for the sale of land and finally, the sale was definitive and led to the loss of all previous rights (Negrão 2001: 217-218). There was also a practice of borrowing land following rules overseen by Mwenes and Samassoas who "could invite the families involved in the transactions to reach an agreement on the land without involving any payment. The tenants were allowed to eat the fruit of the trees but were forbidden to sell them" (Negrão 2001: 214).

One would have expected that the land transactions described above could have been stopped by the post-colonial and socialist government, which proclaimed that all land in Mozambique was a state property and, therefore, it could not be sold, alienated, mortgaged or pledged. But this was not the case since these transactions continued to take place and entered a new phase in the democratic dispensation.

Customary land practices were still strong among the older generation of Micaúne residents at the time of my fieldwork in 2011 and 2012. A case in point is that of Mr. Bruno who, after working in Chinde-Sede as a domestic worker in the 1950s and 1960s, later established himself in Micaúne as an independent tailor. He was able to invest in palm trees, including land, and, through the process, he came to own four big plots, which are still in his possession. Excluding the private farmers and traders' families, he was one of the local people controlling sizable portions of land, according to my informants.

I met Mr. Bruno in 2012 at his well-built house, in the company of his wife. They lived alone as their four children are grown up and married, living in their households. Three of the children left Micaúne some time ago; only the 
last born remained in Micaúne managing his own business. This last son was a successful young entrepreneur as he owned one of the houses left by the colonial traders where he established a shop and ran a workshop for motorbikes. He was also one of the largest holders of livestock.

Mr. Bruno spends his days at home while his wife tries to grow vegetables on one of his four plots next to their house. The other plots were scattered around the area and remained idle, as most palm trees are dead. Considering Mr. Bruno's age, one would have expected that his children would have been actively engaged in their father's holdings, but this is not the case. When asked if his plots were still in his possession, Mr Bruno replied: "Yes but the land has no value because all the palm trees are dead. I can't sell an empty space". ${ }^{4}$ Mr. Bruno epitomises the old principle of land tenure, which attached the value of land to the trees on it. Until recently, direct land transactions among residents were limited, as the value of land depended primarily on palm trees on it.

The widespread death of palm trees associated with CLYD in the 2000s has led to the reconceptualization of the economic value attributed to land. The lengthy economic association between palm trees and land gave way to a clear separation between them. Land regained a market value and it stands on its right as a means of production. Although the sale of land has been common in the area, it has intensified in recent times. This is evident from the following statement by Mr. Lucas, a man in his 40s and a grandson to an important landowner in Micaúne-Sede: "Now that there is no coconut, we must find alternatives. I am capitalising on the land that I inherited from my father to secure a better future for my children". ${ }^{5}$ By capitalising, the informant meant doing different transactions related to the land such as selling, renting and lending. The informant inherited the patrimony from his father, a Madal employee who worked as a machileiro (porters who transported white people in carrying chairs) and who later become an independent carpenter. Upon his father's death, Mr. Lucas inherited the land, which was comprised of eight plots scattered around Micaúne-Sede. Over the years, he was able to acquire, rent and sell some plots whenever he felt the need.

Mr. Lucas is just an example, which encapsulates an approach commonly held by many Micaúne residents in recent times. Despite knowing that it is illegal to sell land, people have claimed that what they were doing was a matter of survival, as evidenced by Mr. Lucas. Moreover, these illegal land dealings might also be an expression of subtle resistance and subversion of state laws as most people feel entitled to engage in dealings on the land they have been occupying for generations. 
This suggests that residents have decided to take a proactive approach to solve their problem instead of just complaining and waiting for someone else to sort it out. Land is crucial because it is currently the main livelihoods asset of the local people since labour and palm trees have ceased to perform that function. The fact that my informant is a secretary of Mugorre neighbourhood, a position in which he has been active since 2008, gives him an advantage in the management of land and the opportunity to know about prospective sellers and buyers. This is because neighbourhood secretaries are the ones who must endorse to the chiefs all land requests in a certain geographic area.

This was evident in a recent land transaction in which Mr. Lucas was involved. The recent electrification of Micaúne in 2012 attracted Movitel, a newly established private mobile operator to the area. The company's staff visited Micaúne to identify a suitable area for the antenna and they identified a certain plot. According to the local authorities, this plot belonged to Mr. Lucas and they advised the company to contact the owner. Movitel staff was able to meet him and close the deal under which he is receiving a monthly payment.

Again, this is an example of how people like Mr. Lucas are capitalising (to use his term) their holdings to generate an income. Madal too has been renting out its Mahimba Game Farm to foreign companies and, to date, the management of this farm included American and, recently, South African companies.

Many people are locally renting out land to generate an income. Most of the people involved in renting land for growing food are people who live at the coast of Micaúne, as there is no sufficient fertile land elsewhere. The payment is in cash or goods depending on the financial situation of the household. When it comes to renting land for housing, it is mainly for the public officials who are in the area temporarily for work purposes. As a result, they do not engage in long-term land use and the houses they build are temporary and precariously constructed with sticks, mud, and grass ceilings. As suggested by White (2010: 513) concerning South Africa, "buildings made with mud and thatch may evoke a sense of insecurity and powerlessness, by contrast to cement buildings which have a claim to permanence".

Although it is rare, the destruction of a house in a rented plot might happen only in an extreme case when replacing an existing house. Normally, they keep and rent out the provisional house to another person. In the case of a tenant refusing to return the house, the matter may lead to conflicts.

Gengenbach (1998: 32) reported a case of conflict in Magude, southern Mozambique, among female farmers who refused to give up borrowed land, and disputes over the proper location of boundaries between cultivated fields. Those conflicts led to the emergence of Xifula witchcraft as a weapon as those newcomers' women who borrowed land, in the end, refused to return it and, instead, started to threaten the owners with witchcraft. This led to conflicts 
between newcomers and locals regarding who does and does not belong to the "cultivating community".

In this instance, newcomers used witchcraft to redress issues of access to land in the area. Although witchcraft accusations are a common feature in my area of study, they are not associated with conflicts between newcomers and locals over access to resources. Neither are there generalised cases of conflicts associated with the refusal to return borrowed land. However, there is the potential for such conflicts to arise and increase due to the growing demand for land, particularly because the number of newcomers with regular income has been increasing year after year.

Mr. Lucas's story contrasts with Mr. Bruno's and exemplifies the changing attitude towards land influenced by commodification. Although this process might benefit those who own land, in the end, it is likely to lead to alienation of the most valued asset and fuel land-associated conflicts as it is already happening in both urban and rural areas throughout the country. These conflicts are likely to happen at two main levels. On the one end, over boundaries, given that the natural landmarks - palm trees - are no more, and, on the other, as the population grows, land is becoming increasingly unavailable and the residents' lack of sources of income will put them at an unfavourable position compared to outsiders who mostly earn a regular income. This is already evident in the salience of the distinction between locals and outsiders, as discussed in the next two sections.

\section{Land as a source of identity}

Place is considered an important aspect of people's identity and belonging (Ponte 2004) and the meanings attributed to places are multiple and depend on people's experiences over time (Rodman 1992). According to Giddens (1984, as quoted in De Haan and Zoomers 2003: 351), a particular locale provides resources and knowledge on which actors can base their action and at the same time it constrains human actions because it binds them to the resources and knowledge provided.

In recent years, land and belonging have featured in the writings that focus on the dichotomy between locals and outsiders, perceived as a source of people's exclusion from participating in politics and the economy (Geschiere and Nyamnjoh 2000; Geschiere 2005, 2009; Lentz 2007). Moreover, the prominence of land, graves, old homes and other landscapes has been a crucial element in the construction and negotiation of belonging by communities (Mujere 2010: 497; see also Shipton 2009).

My research resonates with this literature in as much as the claim of belonging associated with burial sites is concerned. In Micaúne, the dichotomy between locals and outsiders is epitomised and reproduced in every burial event. People have been using their attachment to their ancestors buried in the 
area as one of the main reasons to claim control over the land. As one informant pointed out: "Land does not only have an economic value as a means of production and housing; it has a more profound meaning because it is the home of our ancestors". ${ }^{6}$

Ingold (2000), like other anthropologists, argues that being indigenous assumes that the indigenous or natives are the descendants of those who inhabited a country when colonists arrived from elsewhere. As a result, inhabiting that land is an attribute of an indigenous identity passed on through descendency. This is contradictory because it implies that one's identity depends on his/her genealogical ancestors and not on the attachment to the land.

It is in this genealogical ancestors' sense that Micaúne residents claim their attachment to the land, which suggests that kinship is a crucial element for the understanding of land relations in Micaúne. In this context, my ethnographic material also highlights that land holds a far more key role as an identity marker by establishing linkage to the ancestors as shown by Mr. Faquir's mother example. Mr. Faquir, who at the time was the head of the association of traditional healers, feeling powerless to help his mother when she got seriously ill, decided with his siblings that their mother had to go to Quelimane, the capital city of the province. They felt that she could enjoy not only good medical care but also much better nutritional support. The woman refused to leave the area, claiming that she wanted to stay closer to her father's grave, and she ended up dying there in 2000. Mr. Faquir himself has no plans to leave Micaúne despite complaints about the harsh economic conditions. He claims that he must continue living in Micaúne to take care of both parents' graves.

The claim about people's attachment to land is also applied to people who are away. Locally, people argue that every son of the soil when back from wherever he/she had gone, whether dead or alive, must come to the family place to stay or rest. For this reason, all local families maintain a graveyard inside their plots. These graveyards caught my attention because the tombstones contained several crosses on top of them and I was told that they symbolise the number of people buried there, going back to the founder of the family.

According to one informant, Mr. Silva: "Whenever a family member dies away from home, he is symbolically buried in his family's graveyard". This practice is undertaken to reduce the excessive costs of relocating corpses of those who have died elsewhere back to Micaúne. While the symbolic burials happen in other parts of the country, the difference here is that even though each deceased person is entitled to his or her own grave, because of the scarcity of land, there is only a single grave, which entails adding a cross for each deceased person. Another striking aspect was the quality of and investment in the graves. Due to people's tough economic situations, one would have 
expected to see graves built using simple local materials, which are not costly. On the contrary, cemented and painted graves are part of the local landscape, in stark contrast to the shacks where many people live.

Cementing and painting the graves might symbolically mean that Micaúne residents give immense importance to death. The graveyard symbolises their definitive home as opposed to the shacks where they live, regarded as temporary. As another informant, Mr. Sousa, indicated "we dignify the dead by giving them decent burials and marble graves". ${ }^{7}$ This seems to be a widespread practice among the people who inhabit the lower Zambézia, which includes all the districts south of Quelimane, namely, Quelimane, Inhassunge and Chinde as I had the opportunity to observe during trips in these places.

There is a belief that the ancestors protect their descendants through special powers. Such belief in the power of ancestors was evident during the electrification of Micaúne in 2012. It appears that several years ago Micaúne had never had public electricity supplied and depended on a group of generators, which supplied the village with electricity from $5 \mathrm{pm}$ to 9 pm every day. Although the government has been undertaking a project of rural electrification across the entire country since the country's independence in 1975, electricity reached Micaúne only in 2012. Chinde was the last of the 17 districts of Zambézia province to join the national grid.

The implementation of the electrification project in Micaúne happened via the district of Inhassunge and faced problems, which delayed the conclusion of the project. Apart from the rains, the technical team faced challenges when cutting down trees, some of which were located inside family cemeteries. The government, in coordination with the company assigned to do the job, undertook the establishment of the route of the electric cables excluding local families from the process. The government ordered the company to initiate the cutting of trees and the drilling of holes to sustain the posts, but they were able to cut down only a few trees.

The felling of trees took several months and, as I came to learn later, the problem was associated with a lack of proper consultation with the ancestors of those who owned the areas affected by the project. There was a rumour, which indicated that every time the technicians tried to cut down the trees, they saw blood coming out of the trunks. There was a belief that the trees had grown in a chief's cemetery and to overcome this problem it was necessary to perform a traditional ceremony to appease the ancestors.

Eventually, two months later, the ceremony was performed, which allowed the continuation of the project and it was finalised at the end of 2012. This is an example of how local people perceive their ancestors as their guardians and protectors. Therefore, any initiative on the land must have the endorsement

7 Personal telephone interview conducted with Mr. Sousa on 10 of March 2014. 
of the ancestors to ensure success, while failing to do so might compromise or affect the likelihood of success.

Thus, burial practices make a clear distinction between locals and outsiders. As a result, every funeral reproduces and symbolises this distinction. Only the locals are entitled to having family graveyards. Newcomers do not build graveyards in the area they inhabit because the land does not belong to their ancestors. Sometimes, this distinction emerges in arguments on which natives ask newcomers: "Who are you? Do you have a graveyard?". This is a clear indication showing that newcomers do not belong there.

When the newcomers are unable to send back home the deceased body of their kin, at times due to financial reasons, then, the state's local cemetery becomes an option. However, when newcomers have developed a good relationship, whether friendship or fictive kinship, with a local family, they are, as an exception, allowed to bury their deceased locally, being considered to be something akin to members of the local family in question. There is an exception when the newcomers (mainly public officials) have no friendship or fictive kinship. In such cases, according to Mr. Sousa, the newcomer family requests to bury their loved one in a certain local family's cemetery and, when accepted, payment is required.

The payment covers expenses related to the performance of a ceremony to the local ancestors, as well as for the funeral. However, the burial of the newcomer never happens in the best part of the graveyard, which is under a big tree destined to the owners of the land. In a situation where relatives want to visit the grave of their deceased kin, often they are accompanied by the owners of the cemetery. This suggests that the integration of newcomers is neither immediate nor full. It is a lengthy process and with time, their attachment might grant them the status of natives/locals.

This is the historical process of the incorporation of newcomers into the community. Looking at my case study and considering that there was intense recruitment of labour both by the colonial government and by private companies such as Madal, a considerable number of people who live in Micaúne came from elsewhere. For most of the newcomers, it has been a gradual process of integration. Even the history of the population inhabiting the area shows that the Mahindo are a product of both c-Sena and e-Chuabo ethnic groups. Isaacman and Isaacman (1977: 109) argued that through the fiction of the first arrival the Sena royal lineage in each chieftaincy was successful at attracting and supporting a large following using excess agricultural produce as bridewealth, or chuma, trading slaves with neighbouring ethnic groups, through voluntary enslavement and pawning, and kidnapping.

In brief, family cemeteries reify the construction of otherness and indicate how residents subvert and challenge the notion of the local community as defined in the 1997 land law and other government instruments. According 
to the land law, communities are defined as "a grouping of families and individuals, living in a circumscribed territorial area at the level of a locality or below, which has as its objective the safeguarding of common interests through the protection of areas of habitation and agriculture, whether cultivated or in fallow, forests, sites of socio-cultural importance, grazing lands, water sources and areas for expansion" (Law n. ${ }^{\circ}$ 19/97, article 1/1).

This suggests that newcomers, although legally recognised as members of the local community, are excluded from land rights by the locals on the argument that this is not their ancestral land. It can be argued that it is through this that land-based identity is sanctioned: by excluding the newcomers at the same time it is used as an entitlement to existing resources, as will be explored in the next section.

\section{Land as the reserve of wealth}

When analysing the establishment and development of the coconut economy of Micaúne over the past hundred years, I see a shift from a model of wealth in people and things (Miers and Kopytoff 1977; Guyer 1995), which was consistent with the colonial project of controlling both labour and land, into a triangular force model of wealth existing in-between claims from the market, from commoning and from the state (Rakopoulos and Rio 2018:285). One of the main characteristics of wealth in this late model is its ability to "uphold a trans-temporal function by holding value in store for the future... in-between claims from the market, from commoning and from the state" (Rakopoulos and Rio 2018: 281-285).

In the case of Mozambique, the recent discovery and promise of wealth from minerals have led Micaúne residents to turn into the land as a store of their wealth. This is reinforced by the Mozambican government approval of specific and attractive legislation on minerals, which has an impact on land use. According to the law, "land use for mining operations shall have priority over other land uses whenever economic and social benefits related to these operations are higher" (Law n. ${ }^{\circ} 14 / 2002$, article 43, n. ${ }^{\circ}$ 2).

The way the law is framed leaves no doubt about the supreme value of minerals extraction as compared to any other land use. This, on its own, contributes to people living in areas with minerals to have high expectations about their future. As with local inhabitants and Madal, the government, too, is betting on the idea of anticipation by prioritising any investment in mining extraction. With the anticipated revenues from mineral resources, the government envisaged reducing its dependence on foreign aid, which finances approximately $50 \%$ of the state budget.

This government discourse is likely to contribute to land grabbing given the fact that laws and incentives are attracting high numbers of companies to make investments in natural resources. Nevertheless, one of the effects of 
this government discourse is the instillment of hope in many communities, especially those living at the sites where the minerals are located. For instance, Micaúne residents believe that similar mining developments might occur in their area given its richness in natural resources. There is a strong local belief that there is oil in the Micaúne subsoil following the American company Gulf Oil which undertook oil-prospecting activities in Muguaia in the 1960s and the recent (as from 2000) (re)discovery of huge reserves of minerals as well as the respective extraction. Campbell (2013) notes that Mozambique is currently producing beryl, ilmenite, tantalum, zircon, aluminium, natural gas, heavy sands, coal, lime, phosphate, diatomite and other minerals. By 2013, Mozambique's share of global tantalum production was some $16 \%$, ilmenite around $6 \%$, zircon about $3 \%$ and beryl $1 \%$.

The boom of mineral resources extraction in the country revived the prospects of the Muguaia oil project and the possibility of an alternative and secure source of livelihoods for Micaúne residents. There have been several attempts to determine the viability of oil extraction in Muguaia. In 2005, Petrona, an Italian company, commissioned a public consultation to assess the environmental impact and economic viability of possible oil exploitation in Muguaia, but the study was not conclusive (Achar 2010). Five years later, in May 2010, in a historic visit by a president of the Republic of Mozambique to Micaúne, the people made it clear that there was oil in Muguaia and that the government had to facilitate the process of its extraction. During a public rally in the course of the same visit, an old Micaúne resident stood up and said: "Mr. President, as our palm trees are dying, we request the Government to speed up the mechanisms for the exploitation of that oil deposit; without palm trees, we have no life, so we are please asking you to look for that oil".

The president responded that the amount of oil was too little and there were no companies yet interested in exploiting the existing oil. ${ }^{8}$ Despite the president's negative response, the rumours about oil in Micaúne have not stopped. In 2013, in an interview on the largest and most circulated public newspaper in Mozambique, the provincial director for environmental affairs had to explain that there was no oil in Micaúne. ${ }^{9}$

In 2017, the government of Mozambique through the National Petroleum Institute (INP) contracted the French company Compagnie Générale Geophisic (CGG) to undertake geophysical and geological studies at the maritime bloc of the Zambezi Delta. ${ }^{10}$ One cannot help but deny that there are no natural resources on the subsoil when there is continued research in the area. 
These expectations are creating hope that eventually the Muguaia project will have a successful implementation. This is premised on the expectation that all potential investors, if any, will behave in the same or a better way than Madal, providing not only employment but providing several services in the area. Nevertheless, there are abundant examples across Africa that show that this is not always the case.

In the case of Mozambique, different large-scale projects show that the living conditions of the people in these areas remain precarious (Mosca and Selemane 2011; CIP 2014). Nevertheless, Micaúne residents believe that it is worth trying rather than just sitting and waiting for change (development) to come. Therefore, Micaúne residents have not stopped demanding that the government concretise this project.

Many people, especially the adults and elderly, believe that the granting of the right to extract oil in that area to a private company could solve their livelihood problems. The locals are pushing for the replacement of a monoculture with another potential resource curse in the expectation that everything will be well by just rotating the centre of economic gravity from coconut to oil or other mineral resources.

Apart from oil, there is a belief that Micaúne hosts other minerals, which have been attracting national and foreign investors. A 2012 government mining cadastre shows that the coastal area of Micaúne was under an intense concession for mining prospection, particularly heavy sands, which can be used in ceramics, paints, plastics, paper, aerospace and defence industries, just to mention a few. The staff from the provincial directorate of environmental affairs verbally confirmed this by indicating that the rights to all coastal areas had been granted to investors for mineral prospecting studies. ${ }^{11}$ For instance, in 2007, the government granted a prospecting licence for five years to the Mozambique Natural Resources Corporation LTD in an area of 15.240 hectares. In 2010, a prospecting licence was granted to the Chinese-owned Mozambique Heavysand Mining Company LTD for an area of 16.440 hectares with the license expiring in 2016 (CIP 2012).

The Chinese company Hong Ti Minerals LTD got a prospecting license for titanium in Micaúne in 2011. A year later, in 2012, a prospecting license for ilmenite, rutile and zircon was granted to another Chinese company, Africa Great Wall Mining Development Company, to explore heavy mineral sands in the Chinde (particularly Micaúne), Inhassunge and Nicoadala districts of Zambézia Province.

In 2013 alone, there were three five-year prospecting licenses approved for Micaúne, namely, Di Yuan Minerals LTD from China for ilmenite, rutile and zircon; Cronus Minerals LTD, with Mozambican capital; and Mozambique

11 Personal interview with Mr. Justino in Quelimane on 13 of September 2012. 
Heavysand Mining Company LTD. ${ }^{12}$ As indicated above, most of these investments were still in the prospection phase and, if they materialise in the next few years, they will provide many jobs for the local people and probably will represent an increased investment in infrastructure.

Through the interest manifested by private investors, Micaúne is back on the map and is gradually becoming an investment destination in terms of mineral resources. This might suggest that this area, in years to come, might experience private investments such as those in coal in Tete province. Residents are increasingly becoming aware of the interest of mining companies in future mineral prospecting activity in the area. It is, therefore, not surprising that people hope that their socio-economic conditions are going to change for the better.

To a considerable degree, this explains why Micaúne residents have not migrated for better living conditions elsewhere. Indeed, migration to cities is not an option either given the difficulties for one to establish him/her there, which requires different kinds of skills and assets. Most Micaúne residents can hardly get formal employment in cities because they lack relevant qualifications as well as capital to invest in businesses or acquire land, which are the two most important sources of livelihoods in Mozambican cities.

The implications of such a high demand for land for mineral extraction in Micaúne remain unknown, as the successful implementation of the mines will require the resettlement of residents. Considering the current scarcity of land in the area, there will be an escalation of land conflicts. Indeed, a conflict has arisen recently opposing the Africa Great Wall Mining Development Company and the residents in Deia (Chinde). The latter have been accusing the company of undermining their access to drinking water and land for subsistence crops (Ossumane 2018).

From the discussion above, another concept of land emerged. People consider land as a collective asset, which belongs to, or, at least, should benefit, the local people. This approach expands on the previous concept (land as a source of identity) and differs from the first one (land as a commodity) because of its individual or private focus. Not one of my research participants saw subsoil wealth as belonging to a particular individual, but rather they saw it as the wealth of the Micaúne natives. Somehow, residents feel entitled to the wealth of the soil and have confidence in a renewed cycle of economic stability.

\section{CONCLUSION}

This paper demonstrated how the combination of policy reforms (land law) and an ecological disaster (coconut disease) has led to a change in the way

12 Mozambique Mining Cadastre Portal, available at < http://portals.flexicadastre.com/mozambique/ en/ > (last consulted December 2021). 
people regard land. As a result, land mutated from being the sole preserve of palm production to becoming a commodity in its own right. This paper argued that, despite these concepts of land not being completely new, they became deeply rooted in people's imaginations over time.

The commodification of land has become a prominent feature as land has replaced coconut as the main source from which people can derive their livelihoods. The key outcome of this change is an increasing demand for land for subsistence farming. As argued by Bruce, Fortmann and Riddell (1985) the scarcer land becomes, the more its local value increases. Likewise, this has also triggered claims of attachment to land, which serves as a means of exclusion of newcomers. By claiming that the land in this area belongs to their ancestors, Micaúne natives are advancing their entitlement to existing or to potential wealth from the land. In stark contrast with the dynamics created by the labour enclave economy where workers moved back and forth between urban and rural areas, people have decided to remain in the area, despite the harsh socio-economic conditions. People feel that it is worth waiting for the materialisation of potential big investments than migrating to a place without guaranteed success. The benefits that might come with the extraction of mineral resources remain uncertain.

The expectation that all potential investors, if any, will behave in the same or in a better way than Madal, providing not only employment but promoting the development of the area, is yet to be seen. Nevertheless, the idea of anticipation is keeping all actors' (residents, companies and government) dream of a prosperous future alive. In conclusion, this paper adds to the existing literature in the critique that the land issue in southern Africa should be analysed beyond agricultural production if we are to understand what people do with land to derive their livelihoods. Across the region, there are competing (sometimes conflicting) land use claims and practices linked to the access and management of natural resources. Some of these are linked to nationally and globally resonant discourses encapsulated in the re-appropriation of the imagery and language of environmentalism (Huggins 2018); the conversion of many rural landscapes into nonagricultural housing and recreational properties (Daniels and Bowers 1997); the reference to rural land in terms of social safety nets as a key retirement asset for those living in cities but with connection to the countryside (Geschiere 2005; Ferguson 2013); and the connection between landholding and the funeral Economy (Ferguson 2013) just to mention a few. 


\section{REFERENCES}

ACHAR, Jocas, 2010, "Exploração de petróleo em Micaúne: não temos ainda empresários interessados em explorar furos - afirma Armando Guebuza que trabalhou na região". Available at: < http://macua.blogs.com/moambique_para_todos/2010/05/explora\%C3\% A7\%C3\%A3o-de-petr\%C3\%B3leo-em-mica\%C3\%BAne-n\%C3\%A3o-temos-ainda-empres\%C3\%Al rios-interessados-em-explorar-furos-afirma-armando-guebuz.html > (last consulted January 2022).

ADALIMA, José L., 2020, "Connecting livelihood discourses to land conflicts in central Mozambique", Journal of Contemporary African Studies. DOI: 10.1080/02589001.2020.1774 521.

BERTELSEN, Bjorn E., 2014, "Colonialism in Norwegian and Portuguese: the plantation Madal in Mozambique, 1904-1930", in Kirsten A. Kjerland and Bjorn E. Bertelsen (eds.), Navigating Colonial Orders: Norwegian Entrepreneurship in Africa and Oceania. New York and Oxford: Berghahn Books, 291-320.

BRUCE, John, Louse FORTMANN, and James RIDDELL, 1985, "Trees and tenure: an introduction”, in Louise Fortmann, and James Riddell (eds.), Trees and Tenure: Annotated Bibliography for Agroforesters and Others. Madison, WI: Land Tenure Center (LTC); and Nairobi, Kenya: the International Council for Research in Agro-Forestry (ICRAF): VI-XVII.

CABAÇO, José Luís, 2007, Moçambique: Identidade, Colonialismo e Libertação. São Paulo: Universidade de São Paulo, PhD thesis.

CAMPBELL, Keith, 2013, "Despite risks, Mozambique still seen as attractive for mining", Mining Weekly. Available at < http://www.miningweekly.com/article/despite-risks-mozam bique-still-seen-as-attractive-for-mining-2013-07-19> (last consulted January 2022).

CAPELA, José, 1999, “Conflitos sociais na Zambézia, 1878-1892: a transição do senhorio para a plantação”, Africana Studia 1: 143-173.

CIP - CENTRO DE INTEGRIDADE PÚBLICA, 2012, Cadastro Mineiro de Moçambique: Lista de Licenças. Maputo: CIP.

CIP - CENTRO DE INTEGRIDADE PÚBliCA, 2014, Exploração das Areias Pesadas de Moma: Nem Impostos, Nem Desenvolvimento Económico e Social Local. Maputo: CIP.

CHIMHOWU, Admos, and Phil WOODHOUSE, 2006, "Customary vs private property rights? Dynamics and trajectories of vernacular land markets in Sub-Saharan Africa", Journal of Agrarian Change, 6 (3): 346-371.

DANIELS, Tom and Deborah BOWERS, 1997, Holding Our Ground: Protecting America's Farms and Farmland. Washington, DC: Island Press.

DE HAAN, Leo, and Annelies ZOOMERS, 2003, "Development geography at the crossroads of livelihood and globalisation”, Royal Dutch Geographical Society KNAG, 94 (3): 350-362.

EDEN-GREEN, Simon J., 2006, Executive Summary, Excerpts, and Conclusions of an Assessment of Coconut Lethal Yellowing-type Disease (LYD) in Mozambique. London: EG Consulting (work commissioned by the Millennium Challenge Corporation).

FERGUSON, James, 2013, "How to do things with land: a distributive perspective on rural livelihoods in Southern Africa", Journal of Agrarian Change, 13 (1): 166-174.

FIRST, Ruth, 1983, Black Gold: The Mozambican Miner, Proletarian and Peasant. Sussex: The Harvester Press.

FOALE, Mike, 2003, The Coconut Odyssey: The Bounteous Possibilities of the Tree of Life, ACIAR (Australian Centre for International Agricultural Research), monograph n. ${ }^{\circ} 101$. 
GENGENBACH, Heidi, 1998, "I'll bury you in the border: women's land struggle in post-war Facazisse (Magude District), Mozambique”, Journal of Southern African Studies, 24 (1): 7-36.

GESCHIERE, Peter, 2005, "Funerals and belonging: different patterns in South Cameroon", African Studies Review, 48 (2): 45-64.

GESCHIERE, Peter, 2009, The Perils of Belonging: Autochthony, Citizenship, and Exclusion in Africa and Europe. Chicago: The University of Chicago Press.

GESCHIERE, Peter, and Francis B. NYAMNJOH, 2000, "Capitalism and autochthony: the seesaw of mobility and belonging", Public Culture, 12 (2): 423-452.

GIDDENS, Anthony, 1984, The Constitution of Society: Outline of the Theory of Structuration. Cambridge: Polity Press.

GUYER, Jane I., 1995, "Wealth in people, wealth in things: introduction", Journal of African History, 36 (1): 83-90.

HARRIES, Patrick, 1994, Work, Culture, and Identity: Migrant Laborers in Mozambique and South Africa, c. 1860-1910. Johannesburg: Witwatersrand University Press.

HUGGINS, Chris, 2018, "Land-use planning, digital technologies, and environmental conservation in Tanzania”, Journal of Environment \& Development, 27 (2): 210-235.

INGOLD, Tim, 2000, The Perception of the Environment: Essays on Livelihood, Dwelling and Skill. London: Routledge.

ISAACMAN, Allen F., 1972, Mozambique, the Africanisation of a European Institution: The Zambezi Prazos 1705-1902. Madison: University of Wisconsin Press.

ISAACMAN, Barbara, and Allen F. ISAACMAN, 1977, "Slavery and social stratification among the Sena of Mozambique: a study of the Kaporo system”, in Suzanne Miers and Igor Kopytoff, Slavery in Africa: Historical and Anthropological Perspectives. Madison, WI: University of Wisconsin Press, 105-120.

LASTARRIA-CORNHIEL, Susana, 1997, "Impact of privatization on gender and property rights in Africa”, World Development, 25 (8): 1317-1333.

LENTZ, Carola, 2007, "Land and the politics of belonging in Africa", African Alternatives, 2: 37-58.

MCDOWELL, Christopher, and Arjan DE HAAN, 1997, "Migration and sustainable livelihoods: a critical review of the literature", IDS Working Paper, 65. Brighton: IDS.

MIERS, Suzanne, and Igor KOPYTOFF, 1977, Slavery in Africa: Historical and Anthropological Perspectives. Madison, WI: University of Wisconsin Press.

MOSCA, João, and Thomas SELEMANE, 2011 , El Dorado Tete: Os Mega Projectos de Mineração. Maputo: CIP.

MUJERE, Joseph, 2010, "Land and the politics of belonging in Africa", Journal of the International African Institute, 80 (3): 497-502.

MURAlHA, Pedro, 1925, Terras da África: Moçambique e o Rand. Lisboa: Publicitas. Available at < http://ufdc.ufl.edu/UF00073385/00001/6j > (last consulted January 2022).

NEGRÃO, José, 1995, One Hundred Years of African Rural Family Economy: The Zambezi Delta in Retrospective Analysis. Lund: University of Lund, $\mathrm{PhD}$ thesis.

NEGRÃo, José, 2001, Cem Anos de Economia da Família Rural Africana: o Delta do Zambeze em Análise. Maputo, Promédia (2. ${ }^{\mathrm{a}}$ edição).

NEWITT, Malyn, 1974, "Migrant labour and the development of Mozambique", Collected Seminar Papers, Institute of Commonwealth Studies, 17: 67-76. 
OSSUMANE, Zito do Rosário, 2018, "Exploração de areias pesadas na Zambézia: o pesadelo dos pobres", Txopela. Available at < https://landportal.org/fr/node/74543 > (last consulted January 2022).

PETERS, Pauline E., 2013, "Land appropriation, surplus people and a battle over visions of agrarian futures in Africa”, Journal of Peasant Studies, 40 (3): 537-562.

POLANYI, Karl, 1944, The Great Transformation: The Political and Economic Origin of Our Times. Boston: Beacon Press.

PONTE, Stefano, 2004, “The politics of ownership: Tanzanian coffee policy in the age of liberal reformism", African Affairs, 103 (413): 615-633.

RAKOPOULOS, Theodoros, and Knut RIO, 2018, "Introduction to an anthropology of wealth”, History and Anthropology, 29 (3): 275-291.

RIBEIRO, Caldeira, 1932, "Coqueiros", Boletim da Sociedade de Estudos da Colónia de Moçambique, 1 (5): 127-133.

RITA-FerreirA, António, 1983, Fixação Portuguesa e História Pré-Colonial de Moçambique. Lisboa: Instituto de Investigação Científica Tropical / Junta de Investigações Científicas do Ultramar.

RODMAN, Margaret C., 1992, "Empowering place: multilocality and multivocality", American Anthropologist, (new series) 94 (3): 640-656.

RØNNING, Morten, 2000, Development or Exploitation? Grupo Madal in Mozambique. Oslo: NorWatch.

SERRA, Carlos, 1980, “Capitalismo colonial na Zambézia 1855-1930”, Estudos Moçambicanos, $1: 33-52$.

SHIPTON, Parker, 2009, Mortgaging the Ancestors: Ideologies of Attachment in Africa. New Haven: Yale University Press.

STEPHAN, Christopher, and Devin FLAHERTY, 2019, "Introduction. Experiencing anticipation: anthropological perspectives”, Cambridge Journal of Anthropology, 37 (1): 1-16.

VAIL, Leroy, 1976, "Mozambique's chartered companies: the rule of the feeble", Journal of African History, XVII (3): 389-416.

VAIL, Leroy, and Landeg WHITE, 1980, Capitalism and Colonialism in Mozambique: A Study of Quelimane District. London: Heinemann.

WHITE, Hylton, 2010, "Outside the dwelling of culture: estrangement and difference in postcolonial Zululand”, Anthropological Quarterly, 83 (3): 497-518.

ZAMPARONI, Valdemir D., 1998, Entre Narros e Mulungos: Colonialismo e Paisagem Social em Lourenço Marques c. 1890-c. 1940. São Paulo: Universidade de São Paulo, PhD thesis.

Receção da versão original / Original version

$2019 / 11 / 11$

Aceitação / Accepted

$2020 / 07 / 06$

Pré-publicação online / Pre-published online

$2022 / 01 / 24$ 